\title{
First International Congress of Mongolian Philologists
}

Contributed by Robert A. Rupen

University of North Carolina

The First International Congress of Mongolian Philologists met in Ulan Bator, capital of the Mongolian People's Republic (Outer Mongolia), September I-8, I959. In addition to the many Mongols who participated, twentyeight foreign representatives from fourteen countries attended. The Soviet five-man delegation included three Buryat Mongols and two Russians; the Chinese five-man delegation included two Mongols from Inner Mongolia. The names of the delegates and the countries they represented were:

People's Republic of China. Weng Tu-chien (Peking: Office of Research in Mongolian History, Institute of History of the Chinese Academy of Sciences [head of Chinese delegation]), Huan Dzon-dzing (Peking: National University), Chiu Pu (Küke Khoto, Inner Mongolian Autonomous Region: Association for Study of Mongolian Language), Erdeni Toktoho (Küke Khoto: Institute of Language and Literature), Chinggeltei (Küke Khoto: "Southern Mongolian University").

USSR. Dvoryankov (Moscow: Institute of Oriental Studies of the Academy of Sciences of the USSR [an Iranist; head of Soviet delegation]), Yurii (George) N. Roerich (Moscow: Institute of Oriental Studies), Garma Sanjeev (Moscow: Institute of Oriental Studies), Tsyden-Dambaev (Ulan Ude, Buryat ASSR: Combined Institute of Buryat Language, Literature, and History), Dondukov (Ulan Ude: Combined Institute).

North Korea. Khon Gi Mun. East Germany. Rachnevsky (East Berlin), Johannes Schubert (Leipzig [Tibetan specialist]), Schnura (East Berlin [studying with Sanjeev in Moscow]), Grünert (an archaeologist). Czechoslovakia. Pavel Poucha (Prague: Institute of Oriental Studies). Poland. Kalujinsky (Warsaw). Hungary. Kathe Köhalmi (Budapest [female, pupil of Louis Ligeti]). Rumania. Vladimir Drimba (Bucharest [Turkic specialist]).
Japan. G. Abematsu (Osaka University of Foreign Studies), Koretada Sakamoto (Tokyo University of Foreign Studies), Shizeo Ozawa (Tokyo University of Foreign Studies). India. Raghu Vira (Delhi: International Academy of Indian Culture). Finland. Pentti Aalto (Helsinki).

Great Britain. Charles Bawden (London School of Oriental Studies). Canada. Douglas Jackson (Seattle: University of Washington [geographer]). United States. Udo Posch (Seattle: University of Washington, Far Eastern and Russian Institute), Robert A. Rupen (Chapel Hill: University of North Carolina [Political Scientist]).

This list of conference participants includes many of the world's outstanding Mongolists, but also omits some of the best: Poppe, Cleaves, Hattori, Mostaert, Heissig, Haenisch, and others. Many of these were simply unable to come; certainly the Mongols attempted quite complete representation.

Among the Khalkha Mongols of the Mongolian People's Republic, those most active and most in evidence at the Congress included: Tsevegmid, Chairman of the Mongolian Committee of Sciences and Higher Education, and head of the Congress; Tsendin Damdinsüren, member of the Committee of Sciences and Professor of Mongolian Literature at the State University in Ulan Bator; Rinchen, Director of the Section of Language and Literature of the Scientific Committee, Shadavin Lubsanvandin, member of the Scientific Committee and Visiting Professor of Mongolian Language at the Peking National University; Baldani Sodnom, member of the Scientific Committee; Amagagin Lubsandendev, Scientific Committee member and Organizational Secretary of the Congress; and Sereiter, Scientific Secretary of the Committee of Sciences.

Many other Khalkhas participated actively: those who read papers included, in addition to 
the above, Pagvaa, Oyun (female), Dorji, Tsevel, Vandui, Gombojav, and Mishig. In addition, Khalkhas served as interpreters and secretaries for the Congress. Two Kazakhs from western Outer Mongolia also took part, as did a number of Buddhist lamas from the Kandan Monastery in Ulan Bator.

In addition to the actual sessions from September I-8, many supplementary events were organized for the conferees: visits to the Gandan Monastery, the State Library, the circus, national games, songs and dances, the opera, etc., and especially important were the trips out of Ulan Bator to various important historical and archaeological sites (such as Erdeni Dzu-Kara Korum), from September ro-24.

The Congress itself was a linguistic one, and practically all the papers presented and discussed dealt entirely with that field. Some politically-tinged events occurred, however. The report by the head of the Chinese delegation, Weng Tu-chien, for example, constituted a pure political paean to Mao Tse-tung and the Communist minorities policy. When the Indian representative, Raghu Vira, took the floor to speak of some aspects of Tibetan-Mongol relationships, a Chinese representative (Chiu $\mathrm{Pu}$ ) objected that, "Everybody knows that Tibet has always been part of China." One of the U. S. delegates, Rupen, spoke to the Congress about the life and contributions of the founder of the Mongolian Scientific Committee, Tsyben Jamtsarano, which caused the Soviet (Buryat Mongol) delegate, Sanjeev, to rise and state that Rupen had no right to speak of Jamtsarano. Also, some of the newsreels shown to the delegates included scenes of anti-American demonstrations organized in Ulan Bator to protest U. S. activity in Taiwan.

But these were minor disturbances in fundamentally scholarly meetings. Another important aspect of the Congress was the fine series of publications arranged by the Mongols. These publications were available to the delegates, and testify to the considerable scholarly achievements of the Mongols in recent years.
The publications appear in three series, called "Studia Mongolia," "Studia Folclorica," and "Corpus Scriptorum Mongolorum." They include such items as the long-awaited Russian translation of the Khalkha Jirum (a legal code) by Jamtsarano, catalogues of various manuscripts and bibliographies, folklore collections, a Tibetan-Mongol dictionary, and Damdinsüren's important chrestomathy of Mongolian literature in the old script. These publications represent exceptionally important contributions to Mongolian studies.

The Congress hall included interesting pho tographs of outstanding Mongolists, and it is worthwhile to note whom the Mongols so honor: Choiji Odser, the ancient Tibetan scholar who adapted the Uigur alphabet to the Mongolian language; Pagva; Zaya Pandida, a I $7_{\text {th }}$ century Oirat scholar; Ayushi; Injinashi, an Inner Mongolian author who was the subject of Erdeni Toktoho's paper at the Congress; Jamyang Güng (a Khalkha) and Tsyben Jamtsarano (a Buryat), important in the Mongolian Scientific Committee in the I920's; the Khalkha author, Natsogdorj, subject of the paper by Sodnom; the "first Buryat scholar," Dorji Banzarov; I. J. Schmidt, translator of "Sagang Secen"; Kovalevsky, the compiler of a great Mongolian-Russian-French dictionary; Golstinsky, author of an important MongolianRussian dictionary; Ramstedt, the great Finnish Mongolist; Vladimirtsov, the Russian author of "Social Structure of the Mongols"; Potanin, the famous Russian geographer and traveler; Kotvich, the Polish Mongolist; Paul Pelliot, the great French Mongolian scholar; and Kozin, the Russian translator of Mongolian epic poetry.

The Mongols organized this first International Congress in Ulan Bator very well. English, Chinese, and Russian translation was provided, with earphones supplied for each delegate. The Congress was a significant event, and should mark a new and higher stage in Mongolian studies throughout the world. 